\title{
POTENSI TUMBUHAN OBAT YANG DIGUNAKAN MASYARAKAT MELAYU KOTA JAMBI DI HUTAN KOTA BAGAN PETE KOTA JAMBI
}

\author{
Albayudi $^{1)}$, Zuhratus Saleh ${ }^{2)}$ \\ 1), 2) Fakultas Kehutanan Universitas Jambi \\ email $^{1)}$ : Yudia.bch@gmail.com \\ email ${ }^{2}$ : zuhratussaleh@ymail.com
}

\begin{abstract}
ABSTRAK: Hutan Kota Bagan Pete merupakan salah satu Ruang Terbuka Hijau (RTH) di Kota Jambi. Fungsi RTH sangat bermanfaat sebagai penyangga kehidupan perkotaan. Masyarakat melayu merupakan salah satu etnis yang banyak tinggal di Kota Jambi. Masyarakat melayu di Kota Jambi termasuk sering berinteraksi dan mengetahui serta memanfaatkan tumbuhan secara tradisional dan modern. Penelitian ini bertujuan untuk melihat potensi tumbuhan yang dimanfaatkan masyarakat melayu jambi di Hutan Kota Bagan Pete Kota Jambi. Penelitian ini dilakukan di Hutan Kota Bagan Pete Kota Jambi dari Bulan April-Agustus 2019. Metode yang digunakan adalah eksplorasi langsung terhadap vegetasi tumbuhan yang terdapat di Hutan Kota Bagan Pete dan wawancara mendalam kepada narasumber yang dianggap sesuai mewakili masyarakat etnis melayu Kota Jambi. Penelitian ini menunjukkan bahwa terdapat 68 jenis tumbuhan yang ditemukan selama proses eksplorasi dan 28 jenis tumbuhan diantaranya yang tergabung dalam 21 famili tumbuhan dimanfaatkan oleh masyarakat melayu Kota Jambi sebagai tumbuhan obat. Bagian daun merupakan bagian tumbuhan yang paling banyak dimanfaatkan sebanyak 50\%. Tumbuhan obat tersebut antara lain berfungsi sebagai obat sakit mata, diare, afrodisiak, darah tinggi dan beberapa jenis penyakit lainnya.
\end{abstract}

\section{Kata Kunci : Etnis Melayu, Kota Jambi, Tumbuhan Obat}

\begin{abstract}
The forest pete figure is one of green open space (green space) in the town of Jambi. Space is useful function as a buffer. urban life the malay archipelago is one of many ethnic urban. Jambi the malay archipelago in the town of Jambi often interact and know and use of traditional and modern in this study attempts to assess the potential of malay used by people in the town of Jambi pete. The research was conducted in the forest city charts of the moon pete town of Jambi April-Agustus 2019. Methods used are directly to exploration of vegetation found in the forest a pete and in-depth interviews to speakers who considered appropriate represent the community ethnic malay town of Jambi. The research indicated that there are 68 kinds of herbs found in the process of exploration and 28 tufted herbs of them are joined in 21 the family of plants used by the city malay jambi as plant drug. A foliar part is part of the most commonly used as much as $50 \%$.The drug plants among other things serves as a drug, eye pain diarrhea, an aphrodisiac, high blood pressure and some kind of other diseases.
\end{abstract}

Key word : Malay etnic, Town of Jambi, Medicine plant

Bio-Lectura: Jurnal Pendidikan Biologi, Vol 7, No 1, April 2020 


\section{PENDAHULUAN}

Ruang terbuka hijau (RTH) merupakan solusi yang muncul untuk meningkatkan kualitas lingkungan perkotaan. RTH merupakan kombinasi sistem alam dan manusia dalam lingkungan perkotaan serta merupakan bagian dari penataan ruang suatu kawasan perkotaan yang diisi oleh tumbuhan dan tanaman guna mendukung manfaat ekologi, sosial, budaya, ekonomi, dan estetika, serta berfungsi sebagai kawasan lindung (Fandeli et al., 2004). Secara umum diketahui bahwa RTH telah terbukti memberikan manfaat terhadap kualitas lingkungan seperti membantu memenuhi kebutuhan oksigen (Nurhayati, 2012; Mbele dan Setiawan, 2015; Purba et al, 2018), menjaga habitat satwa liar (Arifin, 2013) serta menjaga pengaturan air tanah (Muis, 2005; Arifin 2013).

Kota Jambi sebagai ibukota provinsi Jambi juga mempunyai beberapa RTH publik dimana salah satu diantaranya adalah Hutan Kota Bagan Pete. Kawasan hutan kota Bagan Pete terletak di kelurahan Bagan Pete Kecamatan Alam Berajo dengan luas areal RTH adalah 41,74 Ha, merupakan zona strategis bagi penyangga kehidupan dengan tutupan lahan yang masih hijau juga merupakan tempat berlindung satwa liar, seperti beberapa jenis burung, jenis reptilia dan kelompok mamalia seperti kera ekor panjang, tupai, babi hutan dan lain-lain.. Hutan Indonesia merupakan sumber daya alam dengan keanekaragaman hayati yang melimpah dan banyak diantaranya mempunyai potensi untuk dikembangkan menjadi sumber daya ekonomi yang strategis. Akan tetapi dari sekian banyak sumber daya hayati, sebagian besar masih belum dikembangkan secara optimal sebagai barang yang bernilai ekonomis, meskipun secara turun temurun dipergunakan sebagai sumber kehidupan yang salah satu diantaranya adalah sebagai obat-obatan.

Provinsi Jambi merupakan salah satu kawasan yang memiliki 4 Taman Nasional, belum lagi beberapa kawasan Lindung dan Taman Hutan Raya termasuk 3 hutan kota yang menjadi zona penyangga kabupaten dan kota yang sangat bermanfaat terhadap kehidupan dan ekosistemnya. Kekayaan alam Provinsi Jambi ini merupakan indikasi keanekaragaman jenis flora yang cukup tinggi termasuk didalamnya tumbuhan obat, yang merupakan bagian dari plasma nutfah yang memiliki peran penting sebagai objek pendataan, penelitian dalam menunjang kegiatan pendidikan dan kehidupan bagi masyarakat Provinsi Jambi. Penggunaan tumbuhan obat sebagai bahan baku obat sudah dilakukan oleh manusia sejak dikenalnya proses meramu dan masih berlangsung hingga kini. Tumbuhan obat digunakan oleh banyak orang karena relatif memiliki efek samping yang kecil dan lebih murah dibandingkan dengan obat-obatan kimia.

Pada era Millenium ini, kecenderungan gaya hidup masyarakat dunia adalah kembali ke alam. Hal ini mengakibatkan penggunaan metode tradisional tidak akan ketinggalan zaman, contohnya di dunia Barat, walaupun masyarakatnya telah berpikiran dan berbudaya dengan 
sangat maju dan modern, sampai sekarang ini kecenderungan untuk menggunakan metode pengobatan atau terapi untuk suatu penyakit dengan metode pengobatan tradisional tetap masih ada. Bahkan ada indikasi terjadinya peningkatan dalam hal penggunaan obat tradisional (Dianawati et al., 2001).

Menurut Wijayakusuma (1994) bagian tumbuhan yang sering dimanfaatkan untuk pengobatan meliputi umbi (tuber), akar (radix), batang (ligua), daun (folia), bunga (flos), buah (fructus), biji (semen), dan seluruh bagian tumbuhan (herb). Pemanfaatan obat tradisional pada umumnya lebih diutamakan sebagai upaya untuk menjaga kesehatan, meskipun ada juga yang menggunakannya untuk pengobatan. Pengobatan tradisional dengan tanaman obat diharapkan dapat dimanfaatkan dalam pembangunan kesehatan masyarakat.

Tumbuhan obat memiliki guna yang berbeda-beda tiap spesiesnya. Habitusnya pun beragam, diantaranya semak, perdu, pohon, epifit, dan lainlain. Untuk itu pengetahuan akan segala sesuatu mengenai tumbuhan obat perlu dikembangkan. Penggunaan obat tradisional meningkat karena beberapa faktor, yaitu harga obatobatan buatan pabrik yang sangat mahal sehingga masyarakat mencari alternative pengobatan yang lebih murah, efek samping yang ditimbulkan oleh obat tradisional sangat kecil dibandingkan dengan obat modern, kandungan kimia yang terkandung di dalam obat tradisional sebenarnya menjadi dasar pengebatan kedokteran.

Pada beberapa kawasan lindung ataupun kawasan konservasi, interaksi antar masyarakat lokal dengan sumber daya alam masih sangat kuat. Bahkan di beberapa lokasi, pola interaksi yang terjalin memberikan kecenderungan positif terhadap kelestarian hutan. Seperti halnya Hutan Kota Bagan Pete yang merupakan kawasan konservasi bagi keberadaan kota Jambi yang seharusnya perlu dijaga dan dipertahankan secara lestari. Interaksi masyarakat sekitar dengan kawasan yang masih berhutan merupakan upaya pemenuhan kebutuhan hidup. Masyarakat sekitar hutan biasanya memiliki pemahaman serta kebiasaan sebagai pengetahuan dalam pemanfaatan sumberdaya alam (Lewerissa, 2015).

Penelitian ini sangat penting artinya bagi masyarakat melayu Jambi jika diperkenalkan dengan semua lapisan masyarakat. Hal ini sebagai pesan bahwa kekayaan alam di Kota Jambi ternyata menyimpan khasiat dan khasanah ilmu pengetahuan sekaligus etik budaya (etnobotani) bagi masyarakat lokal Jambi terutama bagi generasi mendatang tentang pemanfaatan tumbuhan yang diyakini sebagai obat dalam area Hutan Kota Bagan Pete. Penelitian ini secara khusus bertujuan untuk menganalisis keanekaragaman tumbuhan obat berdasarkan stadia vegetasi serta mengumpulkan dan mendokumentasikan pengetahuan masyarakat Melayu Kota Jambi terhadap jenis dan cara pemanfaatan tumbuhan obat berdasarkan stadia vegetasi di Hutan Kota Bagan Pete Kota Jambi.

\section{METODE PENELITIAN}


Penelitian ini dilaksanakan selama 7 (tujuh) bulan dari Bulan Maret sampai dengan Bulan September Tahun 2019. Penelitian ini dilaksanakan di Hutan Kota Bagan Pete, Kota Jambi dan Herbarium Fakultas Kehutanan Universitas Jambi. Alat yang digunakan dalam penelitian ini adalah gunting stek, plastik, kertas label, benang wol, pensil, kertas koran, Global positioning system (GPS), kamera, Tali raffia, Pita Ukur. Adapun bahan yang digunakan dalam pengumpulan sampel yaitu tally sheet, material yang memiliki ciri khas seperti bunga, buah, dan lainnya serta alkohol $70 \%$. Bahan yang lain yaitu Tally sheet dan daftar pertanyaan sebagai bahan panduan dalam wawancara dengan masyarakat sekitar Hutan Kota Bagan Pete. Pemanfaatan bagian tumbuhan baik itu daun, batang, kulit, buah, bunga, dan akar juga dihitung persentasenya. Persentase bagian yang dimanfaatkan dihitung untuk mengetahui berapa besarnya suatu bagian tumbuhan dimanfaatkan terhadap seluruh bagian tumbuhan yang dimanfaatkan. Untuk menghitung persentase digunakan rumus :

Persentase bagian yang dimanfaatkan :

$$
\frac{\Sigma \text { bagian tertentu yang dimanfaatkan }}{\sum \text { seluruh bagian yang dimanfaatkan }} \times 100 \%
$$

Selanjutnya semua data akan dianalisis secara deskriptif dan kuantitatif.

\section{HASIL DAN PEMBAHASAN}

Kawasan hutan kota Bagan Pete terletak di kelurahan Bagan Pete Kecamatan Alam Barajo dengan luas areal RTH 41,74 Ha yang merupakan zona strategis bagi penyangga kehidupan dengan tutupan lahan yang masih hijau juga merupakan tempat berlindung satwa liar seperti beberapa jenis burung, jenis reptilia dan kelompok mamalia seperti kera ekor panjang, tupai, babi hutan dan lainlain. Hutan Kota Bagan Pete adalah salah satu dari Ruang Terbuka Hijau (RTH) yang dimiliki Kota Jambi sangat pontensial untuk dijadikan tujuan wisata atau ekowisata bagi masyarakat kota Jambi. Hutan Kota Bagan Pete (HKBP) sudah memiliki plang nama yang menandakan bahwa HKBP ini adalah bagian Ruang Terbuka Hijau (RTH) yang dikelola oleh pemerintah Kota Jambi. Saat ini HKBP dijadikan tempat untuk menanam pohon bagi calon penganten di Kota Jambi berdasarkan kebijakan pemerintah Kota Jambi.

Eksplorasi tumbuhan obat di HKBP dilakukan secara acak dengan mengamati semua tumbuhan yang ditemui kemudian dicatat dan diambil sampelnya bila perlu. Semua tumbuhan ini kemudian dikonfirmasi dengan masyarakat lokal melayu Kota Jambi yang menemani selama penelitian ini. Hutan Kota Bagan Pete (HKBP) diketahui memiliki berbagai jenis tumbuhan di dalamnya. Beberapa jenis tumbuhan ternyata berpotensi sebagai tumbuhan obat dan diketahui serta kadang digunakan oleh masyarakat melayu yang ada di Kota Jambi. Jenis tumbuhan obat yang ditemukan di HKBP dituliskan pada Tabel 1.

Dari Tabel 1 terlihat bahwa ditemukan 28 jenis tumbuhan obat yang tergabung dalam 21 famili. Hal ini berarti sekitar $42 \%$ dari jenis seluruh tumbuhan yang ditemukan saat eksplorasi dilakukan. Jumlah ini cukup 
besar dan menggambarkan kekayaan pengetahuan masyarakat melayu di Kota Jambi serta memperlihatkan potensi HKBP sebagai penyedia tumbuhan obat. Fungsi HKBP sebagai RTH di Kota Jambi juga sangat mendukung keberadaan tumbuhan obat karena manfaat RTH yang dirasakan masyarakat Kota jambi.
Keberadaan berbagai tumbuhan di RTH akan meningkatkan distribusi oksigen untuk penduduk kota (Nurhayati, 2012; Mbele dan Setiawan, 2015; Purba et al, 2018) serta mampu mempertahankan suhu udara sehingga tidak terlalu panas (Maru dan Ahmad, 2015).

Tabel 1. Jenis Tumbuhan yang Dimanfaatkan Sebagai Obat bagi Suku Melayu Jambi di Hutan Kota Bagan Pete

\begin{tabular}{|c|c|c|c|c|}
\hline No. & Nama Tumbuhan & Nama Latin & Suku/Famili & $\begin{array}{c}\text { Bagian yang } \\
\text { Digunakan }\end{array}$ \\
\hline 1. & Sekuang & Dracontomelon dao & Anacardiaceae & Kulit batang \\
\hline 2. & Kayu Sigam & $\begin{array}{l}\text { Polyalthia rumphii } \\
\text { (BI). Merr }\end{array}$ & Annonaceae & Daun muda \\
\hline 3. & $\begin{array}{c}\text { Pisang- } \\
\text { Pisang/antui }\end{array}$ & Cyathocayx sp & Annocaceae & Batang \\
\hline 4. & Pulai Gading & Alstonia scholaris & Apocynaceae & Getah, Daun Muda \\
\hline 5. & Asam Kandis & $\begin{array}{c}\text { Garcinia } \\
\text { xanthochymus }\end{array}$ & Clusiaceae & Buah \\
\hline 6. & Amplas Kijang & Tetracera scandes L. & Dilleniaceae & Batang, akar \\
\hline 7. & Sebasa & $\begin{array}{c}\text { Aporosa frutescens } \\
\text { Blume }\end{array}$ & Euphobiaceae & Pucuk dan Kulit \\
\hline 8. & Kayu Gulo & $\begin{array}{c}\text { Ryparosa caesia } \\
\text { Kurz. Ex King }\end{array}$ & Euphorbiaceae & Daun \\
\hline 9. & Mahang & Macaranga gigantae & Euphorbiaceae & Daun dan Akar \\
\hline 10. & Kayu Tulang & $\begin{array}{l}\text { Galearia filiformis } \\
\text { (BI). Boerl. }\end{array}$ & Euphorbiaceae & Pucuk daun \\
\hline 11. & Kabau & Archidendron sp & Fabaceae & Buah \\
\hline 12. & Sebekal & Forelia johorensis & Fabaceae & Daun \\
\hline 13. & Tembesu Angin & $\begin{array}{l}\text { Tabernaenmontana } \\
\text { sp. }\end{array}$ & Gentianaceae & Pucuk daun \\
\hline 14. & Kayu Tubung & $\begin{array}{c}\text { Gonocaryum gracile } \\
\text { Miq }\end{array}$ & Icacinaciae & Daun Muda \\
\hline 15. & Keranji & Dialium indum & Leguminoceae & Buah dan daun \\
\hline 16. & Senduduk & Melastoma candidum & Melastomaceae & Daun \\
\hline 17. & Cempedak Air & $\begin{array}{l}\text { Artocarpus } \\
\text { champeden }\end{array}$ & Moraceae & Kulit Batang, buah \\
\hline 18. & Kayu Terap & $\begin{array}{l}\text { Artocarpus } \\
\text { odoratisimus }\end{array}$ & Moraceae & Pucuk Daun \\
\hline 19. & Ubi-Ubi & $\begin{array}{c}\text { Rapanea hasseltii } \\
\text { Mez. }\end{array}$ & Myrsinaceae & Pucuk Daun \\
\hline 20. & Merepuyan & $\begin{array}{c}\text { Rhodamnia cinerea } \\
\text { Jack }\end{array}$ & Myrtaceae & Kulit Batang \\
\hline 21. & Karamunting & $\begin{array}{c}\text { Rhodomyrtus } \\
\text { tomentosa }\end{array}$ & Myrtaceae & Pucuk daun \\
\hline 22. & Petaling & $\begin{array}{c}\text { Ochanostachys } \\
\text { amentaceae }\end{array}$ & Olacaceae & Pucuk daun \\
\hline
\end{tabular}




\begin{tabular}{|c|c|c|c|c|}
\hline 23. & Pasak Bumi & $\begin{array}{c}\text { Eurycoma longifolia } \\
\text { Jack }\end{array}$ & Simaroubaceae & Akar \\
\hline 24. & Kecubung & Datura metel L. & Solanaceae & Daun \\
\hline 25. & Kayu Menyan & $\begin{array}{l}\text { Styrax benzoin } \\
\text { Dryand }\end{array}$ & Styracaceae & Getah \\
\hline 26. & Siluk & $\begin{array}{c}\text { Gironiera nervosa } \\
\text { Planch }\end{array}$ & Ulmaceae & Daun, akar \\
\hline 27. & Leban & Vitex pinnata & $\begin{array}{l}\text { Verbenaceae/Lamiace } \\
\text { ae }\end{array}$ & Kulit Batang \\
\hline 28. & Puar & Атотит sp & Zingiberaceae & Bunga, daun \\
\hline
\end{tabular}

\section{Selanjutnya komposisi} tumbuhan obat yang ditemukan ini dapat pula dibedakan berdasarkan bagian tumbuhan yang dipakai untuk pengobatan (Gambar 1). Dari Gambar ini terlihat bahwa bagian daun menjadi bagian yang paling banyak dimanfaatkan yaitu sebesar $50 \%$ dari semua jenis yang ditemukan. Bagian lain seperti akar, batang, kulit dan buah juga dimanfaatkan tetapi persentasenya tidak sebesar bagian daun. Temuan ini sejalan dengan penelitian Sada dan Tanjung (2010) terhadap pemanfaatan obat di papua dimana pemanfaatan bagian dau mencapai $52 \%$ dibandingkan dengan bagian tumbuhn lainnya. Hal ini sering terjadi dalam pemanfaatan tumbuhan obat karena bagian daun biasanya lebih mudah didapatkan dan diolah. Bagian daun juga seringkali lebih kaya dengan metabolit sekunder tumbuhan yang menjadi sumber alami dari bahan obat tersebut (Simorangkir et al., 2017). Beberapa metabolit skunder yang biasa ada di tumbuhan diantaranya golongan minyak atsiri, flavonoid, alkaloid, steroid, dan triterpenoid (Hernani 2011).

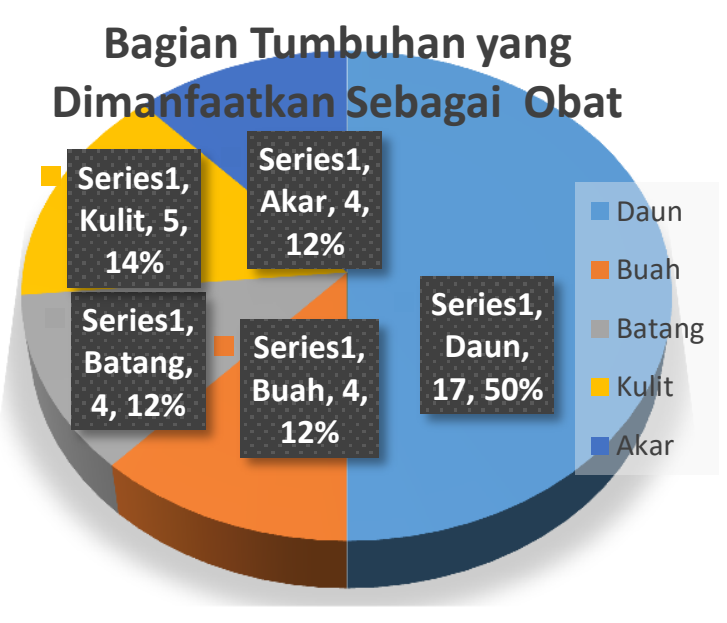

Gambar 1. Persentase bagian tumbuhan yang dimanfaatkan sebagai obat

Penggunaan tumbuhan obat yang ditemukan tersebut juga ternyata diaplikasikan untuk mengobati berbagai penyakit. Beberapa penyakit yang bisa diobati dengan tumbuhan yang didapatkan pada penelitian ini antara lain:

1. Obat Malaria dan Demam

Malaria merupakan penyakit yang sering ditemukan pada daerah tropis. Namun alam sebagai ciptaan tuhan biasanya selalu menyediakan obat dari penyakit yang ada di sekitarnya.Beberapa jenis tumbuhan obat yang diketahui sebagai obat malaria pada penelitian ini adalah Cempedak Air (Artocarpus campeden), Pasak Bumi (Eurycoma 
longifolia) dan Puar (Amomum sp./Zingiberaceae). Obat demam antara lain Sebasa (Aporosa frutescens), Mahang (Macaranga gigantea), Kayu Tubung (Gonoracyum gracile) dan Ubi-Ubi (Rapanea hasseltii).

2. Obat Sakit Pencernaan

Masalah pencernaan merupakan yang sering terjadi pada masyarakat terutama pada kelompok yang sering berinteraksi dengan lingkungan tanpa memperhatikan kebersihannya. Penyakit pada bagian pencernaan yang sering ditenui antara lain ambeien, diare, disentri, perut kembung, maag dan susah buang air besar. Beberapa jenis tumbuhan obat yang ditemukan pada penelitian ini diketahui bisa mengobati penyakit tersebut yaitu Sekuang (Dracontomelon dao), Mahang (Macaranga gigantea), Kabau (Archidendron sp.), Tembesu Angin (Tabernaenmontana sp.), Keranji (Diallium indum), Kecubung (Datura metel) dan Kemenyan (Styrax benzoin).

3. Pelancar Kelahiran

Proses melahirkan normal bisanya cenderung sulit dilakukan terutama pada kelahiran pertama. Masyarakat tradisional bisanya menggunakan beberapa jenis tumbuhan yang diketahui mampu dan menimbulkan efek memperlancar dalam proses melahirkan. Jenis tumbuhan tersebut diantaranya adalah Pisangpisang (Cathocalyx sp.), Kayu Tulang (Galearia filiformis) dan Kayu Terap (Artocarpus sp.).

4. Kencing Manis, Kolesterol dan Hipertensi
Tiga jenis kondisi ini sering ditemukan pada usia lanjut dan generasi muda milenial. Kondisi ini sering terjadi karena kurangnya gerak, pola makan yang salah serta makanan yang tidak seimbang. Beberapa jenis yang dapat mengobati atau mencegah kondisi ini diantaranya Kabau (Archidendron sp.), Keranji (Diallium indum), Karamunting (Rhodomyrtus tomentosa) dan ), Pasak Bumi (Eurycoma longifolia). 5. Masalah Pernafasan Beberapa masalah pernafasan yang serig timbul adalah sesak nafas dan batuk. Diantara tumbuhan yang diketahui bisa menjadi obatnya adalah Amplas Kijang (Tetracera scandens),

Petaling (Ochanostrachys amentacea) dan Kemenyan (Styrax benzoin).

6. Obat Luar

Obat luar yang dimaksud bisa saja obat luka, obat mata dan bengkak. Beberapa jenis tumbuhan obat yang digunakan antara lain Mahang (Macaranga gigantea), Kayu Tubung (Gonoracyum gracile), Senduduk (Melastoma malabathricum), Ubi-Ubi (Rapanea hasseltii), Kemenyan (Styrax benzoin) dan Puar (Amomum sp.).

7. Afrodosiak

Afrodisiak adalah istilah untuk obat yang meningkatkan kehidupan seksual pria. Beberapa tumbuhan diketahui dimanfaatkan oleh masyarakat melayu sebagai afrodisiak alami seperti Kayu Gulo (Ryparosa caesia) dan Pasak Bumi (Eurycoma longifolia). 


\begin{abstract}
Pengetahuan masyarakat melayu Kota Jambi dalam memanfaatkan tumbuhan ternyata mirip dengan cara pemanfaatan suku lainnya di dunia. Sekuang (Dracontomelon draco) ternyata juga dimanfaatkan masyarakat di Filipina sebagai obat disentri dan telah diteliti lebih lanjut dalam ilmu farmasi untuk pemanfaatan di bidang kesehatan (Ragasa et al, 2017). Demikian juga dengan Pasak Bumi (Eurycoma longifolia) yang juga dimanfaatkan sebagai obat malaria oleh suku anak dalam (SAD) di wilayah provinsi Jambi (Indriati, 2014).

Pengetahuan lokal masyarakat melayu di Kota Jambi ternyata masih cukup banyak yang perlu dieksplorasi. HKBP juga menyimpan berbagai potensi tumbuhan obat yang perlu diketahui dan dilestarikan. Gabungan kondisi inilah yang harus diperhatikan dalam usaha konservasi berkelanjutan di ruang terbuka hijau di Kota Jambi dan masyarakat yang hidup di dalamnya.
\end{abstract}

\section{KESIMPULAN}

Penelitian yang telah dilaksanakan sejauh ini mendapatkan kesimpulan bahwa pada lokasi penelitian terdapat 28 spesies tumbuhan obat yang tergabung dalam 21 famili. Tumbuhan obat ini didapatkan dalam berbagai habitus seperti pohon, semak dan herba. Bagian tumbuhan yang paling banyak dimanfaatkan adalah daun sebanyak $50 \%$ diikuti bagian lainnya seperti akar, batang, kulit dan akar.

\section{UCAPAN TERIMA KASIH}

Terima kasih kami ucapkan kepada pihak pemerintah Kota Jambi selaku pengelola Hutan Kota Bagan Pete serta para mahasiswa dan masyarakat narasumber lokal yang telah membantu jalannya penelitian ini. Penelitian ini terlaksana dengan dana PNBN Fakultas Kehutanan Universitas Jambi Tahun 2019.

\section{DAFTAR PUSTAKA}

Arifin, S. S. 2013. Analisis kebutuhan ruang terbuka hijau Kecamatan Kota Tengah Kota Gorontalo. (skripsi). Universitas Negeri Gorontalo, Gorontalo.

Dianawati, A. dan Irawan, E.S. 2001. Ramuan Tradisional. Cetakan Kedua. PT Agro Media Pustaka. Jakarta.

Fandeli, C., Kaharudin and Mukhlison. 2004. Perhutanan Kota. Fakultas Kehutanan UGM, Yogyakarta.

Hernani. 2011. Pengembangan biofarmaka sebagai obat herbal untuk kesehatan. Buletin Teknologi Pascapanen Pertanian 7(1):2029.

Indriati, G. 2014. Etnobotani tumbuhan obat yang digunakan suku Anak dalam di Desa Tabun Kecamatan VII Koto Kabupaten tebo jambi. Jurnal Sainstek 6(1): 52-56.

Lewerissa E. 2015. Interaksi Masyarakat Sekitar Hutan Terhadap Pemanfaatan Sumber Daya Hutan di Desa Wangongira, Kecamatan Tobelo Barat. Jurnal Agroforestri X (1) :11-20.

Maru, R. and Ahmad, S. 2015. The relationship between temperature patterns and urban morfometri in The Jakarta City, Indonesia. Asian Journal of Atmospheric Environment 
9(2),:128-136,

DOI:http://dx.doi.org/10.5572/ ajae.2015.9.2.128.

Mbele, M. F. B and Setiawan, R. P. 2015. Penyediaan ruang terbuka hijau berdasarkan kebutuhan oksigen di Kota Malang. Jurnal Teknik ITS 4(2): 98-101.

Muis, B. A. 2005. Analisis kebutuhan ruang terbuka hijau berdasarkan kebutuhan oksigen dan air di Kota Depok Propinsi Jawa Barat. (Tesis). Sekolah Pascasarjana. Institut Pertanian Bogor. Bogor.

Nurhayati, H. 2012. Analisis kebutuhan ruang terbuka hijau berdasarkan kebutuhan oksigen (studi kasus Kota Semarang). Skripsi. Fakultas Matematika dan Ilmu Pengetahuan Alam. Institut Pertanian Bogor. Bogor.

Purba, D., Subiyanto, S and Hani'ah. 2018. analisis kebutuhan ruang terbuka hijau berdasarkan pendekatan kebutuhan oksigen di Kota Pekalongan dengan menggunakan penginderaan jauh dan sistem informasi geografis. Jurnal Geodesi Undip 7(4): 264-273.

Ragasa, C., Y, Batarra, T., C, Vivar, J. L. A., De Los Reyes, M. M., Shen, C. C. 2017. Chemical Constituents of Dracontomelon Dao (Blanco) Merr. et Rolfe. Pharmacogn $J$ 9(5):654-656.

Sada, J dan Tanjung, R. H. R. 2010. Keragaman Tumbuhan Obat Tradisional di Kampung Nansfori Distrik Supiori Utara, Kabupaten Supiori-Papua. Jurnal Biologi Papua 2 (2): 39-46.
Simorangkir, M., Surbakti, R., Barus, T., Simanjuntak, P. 2017. Analisis Fitokimia Metabolit Sekunder Ekstrak Daun dan Buah Solanum blumei Nees ex Blume lokal. Jurnal Pendidikan Kimia (JPKim) 9(1): 244-248. DOI: https://doi.org/10.24114/jpkim.v9i 1.6186

Wijayakusuma, H., 1994, Tumbuhan Berkhasiat Obat Indonesia . Prestasi Intan Indonesia. Jakarta 